\title{
Etiology and Treatment of Renal Forniceal Rupture: A Single Center Experience
}

\author{
Renal Forniks Rüptürü Etiyolojisi ve Tedavisi: Tek Merkez Deneyimi
}

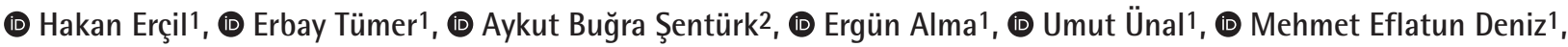 \\ (D) Yalçın Kaya Evliyaoğlu1, (D) Zafer Gökhan Gürbüz1 \\ 'Adana Numune Training and Research Hospital, Clinic of Urology, Adana, Turkiye \\ 2 Hitit University Çorum Erol Olçok Training and Research Hospital, Clinic of Urology, Çorum, Turkiye
}

\section{What's known on the subject? and What does the study add?}

Our study is one of the best series about the subject. It will also guide all urologists as their treatment modalities are assessed.

\begin{abstract}
Objective: To evaluate the clinical findings, treatment methods and outcomes of patients treated for renal forniceal rupture (RFR).

Materials and Methods: Files and records of the patients treated for RFR between January 2013 and November 2016 were evaluated retrospectively. In primary treatment; ureteroscopy and laser/pneumatic lithotripsy (URL) with stone fragmentation and double J (JJ) stent placement were performed in patients with no finding of sepsis. However, only JJ stent/percutaneous nephrostomy placement was performed in those with sepsis findings. The demographic characteristics, related symptoms, and the results of primary and secondary treatment of the patients were evaluated.

Results: We had 43 patients with a mean age of $48.6 \pm 16.6$ years. No cause was found in 4 patients while a urological cause was identified in 39 of them by using anamnesis, physical examination, laboratory and imaging methods. Out of 43 patients, percutaneous nephrostomy catheterization was performed in 5 of 32 patients under primary treatment. URL and JJ stenting were performed in the remaining 11 patients. Additionally, due to giant retroperitoneal urinoma, a retroperitoneal drain was placed in 2 patients by interventional radiology clinic.

Conclusion: URL and stone fragmentation seem to be feasible treatment option in the primary treatment of patients with RFR without sepsis findings.
\end{abstract}

Keywords: Fornix rupture, Urinoma, Urolithiasis, Primary ureteroscopic treatment, Urology

Öz

Amaç: Renal forniks rüptürü (RFR) sebebi ile tedavi ettiğimiz hastaların klinik bulguları, tedavi yöntemleri ve sonuçlarını değerlendirmeyi amaçladık. Gereç ve Yöntem: 2013 0cak-2016 Kasım tarihleri arasında RFR sebebi ile tedavi ettiğimiz hastaların dosyaları ve bilgisayar kayıtları retrospektif olarak değerlendirildi. Hastaların tamamına öncelikle ampirik tedavi başlandı. İdrar kültürü-antibiyogram sonucuna göre gerekli görülen hastalarda seftriakson uygun olan başka bir antibiyotik ile değiştirildi. Sepsis bulgularının olmaması durumunda tedavi olarak üreteroskopi ve lazer/pnömotik litotriptör (ÜRL) ile taş fragmantasyonu ve double J (DJ) stent yerleştirilmesi ameliyatı yapılmıştı. Ancak; sepsis bulgularının olması durumunda tek başına DJ stent/perkütan nefrostomi yerleştirilmesi yapılmıştı. Hastaların demografik özellikleri, ilişkili semptomları, primer ve sekonder tedavilerinin sonuçları değerlendirildi.

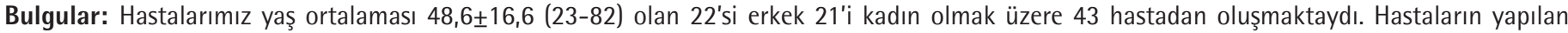
anamnez, fizik muayene, laboratuvar ve görüntüleme yöntemleri ile 4'ünde sebep bulunamazken, 39'unda ürolojik bir sebep saptandı. Kırk üç hastanın 32'sinde hastaya acil tedavide 5 hastaya perkütan nefrostomi kateteri konulurken, 27 hastaya lokal anestezi altında sistoskopi eşliğinde DJ stent takıldı. Geri kalan 11 hastaya ise ÜRL ile taş fragmantasyonu ve DJ stent yerleştirilmesi yapılmıştı. Ayrıca 2 hastaya dev ürinom sebebi ile retroperitoneal dren yerleştirilmiş̧i.

Sonuç: Her iki grup tedavi başarısı ve komplikasyonlar açısından değerlendirildiğinde fark olmadığı düşünülürse, sepsis bulguları olmayan spontan RFR'si olan hastalarda öncelikli tedavide ÜRL ve taş fragmantasyonu uygulanabilir bir tedavi gibi görünmektedir.

Anahtar Kelimeler: Forniks rüptürü, Ürinom, Taş hastalığı, Öncelikli üreteroskopik tedavi, Üroloji

Correspondence: Hakan Erçil MD, Adana Numune Training and Research Hospital, Clinic of Urology, Adana, Turkiye

Phone: +90 3223550101 E-mail: hakanercil@yahoo.com ORCID-ID: orcid.org/0000-0001-7103-7597

Received: 12.10.2017 Accepted: 11.02.2018

Cite this article as: Erçil H, Tümer E, Sentürk AB, Alma E, Ünal U, Deniz ME, Evliyaoğlu YK, Gürbüz ZG. Etiology and Treatment of Renal Forniceal Rupture:

A Single Center Experience. J Urol Surg 2018;5(2):68-72.

बCopyright 2018 by the Association of Urological Surgery / Journal of Urological Surgery published by Galenos Publishing House. 


\section{Introduction}

Renal forniceal rupture (RFR) is a potential urological emergency, although it is a rare result of obstructive uropathy. It often emerges as a secondary to obstruction of the ureter or ureteropelvic junction and generally occurs in the upper and lower renal pole calyces $(1,2)$. Extravasated urine may accumulate in the extraperitoneal area, inside the peritoneal cavity, or both. The extraperitoneal collection can be formed as two types: subcapsular and perirenal. Subcapsular urinomas occur between the renal parenchyma and the renal capsule whereas perirenal urinomas are between the renal capsule and the Gerota's fascia.

Retroperitoneal urinoma can lead to a clinical picture that is indistinguishable from simple renal colic. Preoperative diagnosis becomes more difficult due to blood loss and generally lack of urinary symptoms $(3,4)$. One of the major clinical findings is sudden pain relief due to decreased pressure in the collecting system (5). Prognosis varies according to underlying pathology, renal injury, place of rupture and presence of infection (6). If this formed urinoma is not treated, it may result in perirenal abscess formation, sepsis, retroperitoneal fibrosis, loss of renal function, and even death $(7,8,9,10)$.

When urological literature related to RFR is examined, it can be seen that there are many case reports except two studies. In this study, we aimed to evaluate the clinical findings, treatment methods and outcomes of the patients treated for RFR.

\section{Materials and Methods}

Following the approval (decision number: 175/2018) from the Ethics Committee of Adana City Training and Research Hospital, the files and records of patients treated for RFR between January 2013 and November 2016 were evaluated retrospectively. A consent form was completed by all participants. The patients who were assessed and hospitalized in our clinic were referred by the emergency department or urology outpatient clinic. RFR diagnosis was made by radiological imaging methods. Primarily, kidney-ureter-bladder X-ray and abdominal ultrasonography (USG) were performed in all patients and abdominal computed tomography (CT) was performed to confirm the diagnosis and determine the etiology. Following the hospitalization, all patients were evaluated with vital signs, urine analysis, urine culture-antibiogram, serum blood urea nitrogen and creatinine levels, white blood cell count (WBC) and C-reactive protein (CRP). All patients primarily received empirical treatment (analgesia, intravenous fluids, empiric ceftriaxone, and bed rest). Ceftriaxone was switched to another antibiotic when necessary according to the results of urine culture-antibiogram. In primary treatment, ureteroscopy and laser/pneumatic lithotripsy (URL) with stone fragmentation and double $\mathrm{J}(\mathrm{JJ})$ stent placement were performed; in patients with no findings of sepsis (e.g. fever, increased WBC, increased CRP, etc.) (group 1). However, only JJ stent/percutaneous nephrostomy placement was performed in those with findings of sepsis (group 2). Additionally, the secondary treatment was applied to the patients of group 2 in a separate surgical session according to their RFR etiology.

The laboratory tests were repeated at every 48-72 hours until normal levels were reached. During the patients' hospitalization, the size of urinomas was monitored by USG at every 48 hours following surgical treatment. The patients followed up with USG every 15 days after discharge.

The demographic characteristics, related symptoms, and the results of primary and secondary treatment of the patients were evaluated.

\section{Results}

\section{Demographic Characteristics and Clinical and Diagnostic Findings}

A total of 43 patients ( 22 men and 21 women) with a mean age of $48.6 \pm 16.6$ (23-82) were included in the study. RFR was on the left side in 24 patients and on the right side in 19 patients. Flank pain occurred in all patients (100\%), fever in 15 patients (34.8\%), emesis in 7 patients $(16.3 \%)$ and hematuria in 4 patients $(9.3 \%)$.

No cause was found in 4 patients (9.3\%) while a urological cause was identified in 39 of them by using anamnesis, physical examination, laboratory and imaging methods. Ureteric stones were found in 32 of these 39 patients $(74.4 \%)$, stones were found in the uretero-pelvic region in 6 patients $(14 \%)$ and bladder tumors were found in one patient (2.3\%). The number of patients with ureteric stones within the upper, middle and lower ureter was $6,3,23$, respectively. Twenty six (81.2\%) of these ureteric stones were impacted stones. Of the 4 patients in whom the cause of RFR could not be determined, 3 had a medical history of stone surgery or passing stones.

When all patients were evaluated; it was found that 3 patients had a solitary and the other kidney was atrophic in 5 patients. It was detected that 26 patients had elevated WBC (>103) $\mu \mathrm{L}), 26$ patients had CRP elevation ( $>5 \mathrm{mg} / \mathrm{L}$ ) and 16 patients had elevated creatinine $(>1.2 \mathrm{mg} / \mathrm{dL})$. The demographic characteristics and clinical and laboratory findings of the patients are shown in Table 1. In group 1 patients, all urine analyses were unsuggestive for possible infection. Urine culture was negative in all the group 1 patients, however, it was positive in 15 patients of group 2 (46.8\%). The microorganisms identified in the urine culture are shown in Table 2. 


\section{Treatment}

Out of 43 patients, percutaneous nephrostomy catheterization was performed in 5 of 32 patients (group 2) under primary treatment. JJ stents were implanted in 27 patients under local anesthesia with cystoscopy. URL and JJ stenting were performed in the remaining 11 patients (group 1). Additionally, due to giant retroperitoneal urinoma, a retroperitoneal drain was placed in 2 patients by the interventional radiology clinic (Figure 1).

Table 1. Demographic, clinical and diagnostic findings

\begin{tabular}{llll}
\hline Parameters & Group 1 & Group 2 & Result \\
\hline Number of patients & 11 & 32 & 43 \\
Male/female & $5 / 6$ & $17 / 15$ & $22 / 21$ \\
$\begin{array}{l}\text { Right/left kidneys } \\
\text { involved }\end{array}$ & $7 / 4$ & $17 / 15$ & $24 / 19$ \\
$\begin{array}{l}\text { Symptom } \\
\text { Pain }\end{array}$ & & & \\
Fever & 11 & 32 & 43 \\
$\begin{array}{l}\text { Emesis } \\
\text { Hematuria }\end{array}$ & 2 & 13 & 15 \\
$\begin{array}{l}\text { Underlying cause of } \\
\text { fornix rupture }\end{array}$ & 1 & 6 & 7 \\
$\begin{array}{l}\text { Ureter stones } \\
\text { Kidney stones }\end{array}$ & 11 & 3 & 4 \\
$\begin{array}{l}\text { Bladder tumors } \\
\text { Unknown }\end{array}$ & 0 & 21 & 32 \\
$\begin{array}{l}\text { C-reactive protein } \\
\text { elevation }\end{array}$ & 3 & 6 & 6 \\
Leukocytosis & 4 & 1 & 1 \\
Creatinine elevation & 4 & 4 & 4 \\
\hline
\end{tabular}

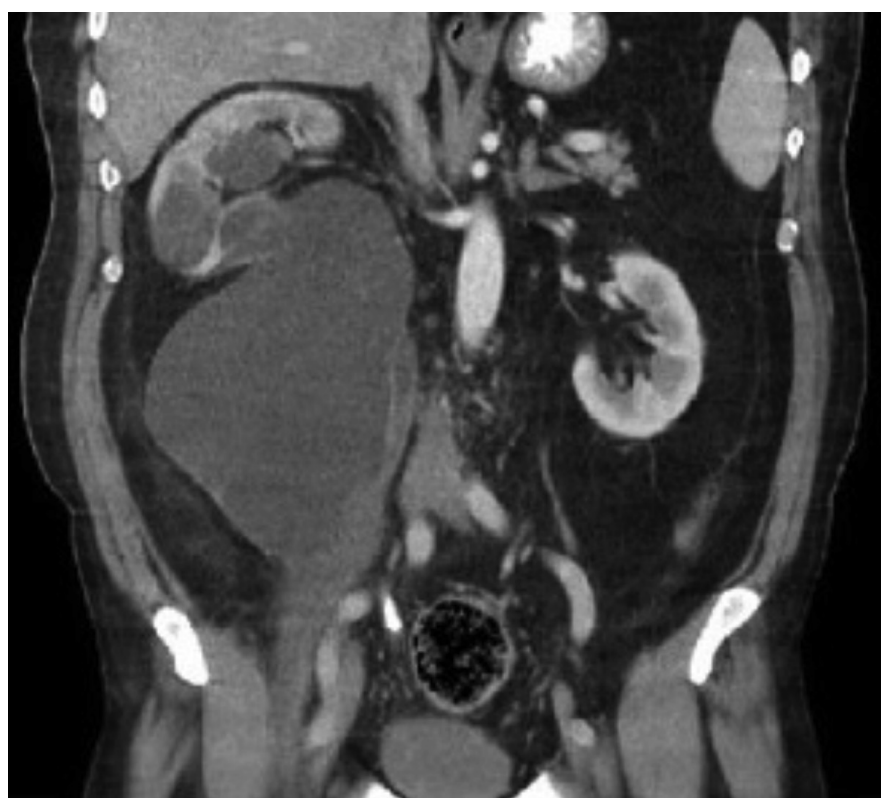

Figure 1. The computerized tomography image of fornix rupture
In the secondary treatment of 32 patients, who underwent JJ stent or percutaneous nephrostomy catheter placement in the primary treatment, ureteroscopic stone fragmentation and $\mathrm{JJ}$ stent placement were performed in 20 patients, percutaneous nephrolithotomy in 4 patients, flexible ureteroscopy in 2 patients, extracorporeal shock wave lithotripsy in 1 patient and radical cystectomy in 1 patient. In 4 patients with no cause of RFR, only $\mathrm{JJ}$ stenting was performed. Retroperitoneal urinary retention and kidney functions were found to be preserved these 4 patients in the follow-up period. The mean time to transition from the primary treatment to the secondary treatment was calculated as $29.5 \pm 6.7$ days $(20-42)$. The mean duration of hospital stay was $7.6 \pm 4.7(2-25)$ days. The treatment methods are shown in Table 3.

During the follow-ups of patients, no major complication occurred in the early and late periods.

\section{Discussion}

RFR is a very rare clinical diagnosis and the most common cause of obstructive uropathy due to urethral stones $(1,3)$. Rarely, it can occur due to blunt trauma or sharp object injuries, invasive urinary procedures, tumor obstruction and pregnancy $(11,12,13)$. There are many opinions about the physiopathology of urinoma, most of which are chronic ureteral obstruction resulting in pyelosinus back-flow, renal sinus extravasation with

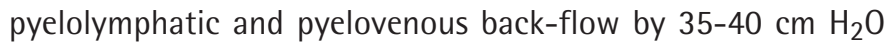
and/or more increase in intrapelvic pressure, and therefore the resultant perirenal extravasation (14).

Table 2. Microorganisms breeding in urine culture

\begin{tabular}{ll}
\hline Microorganisms & Number of patient \\
Escherichia coli & 8 \\
Pseudomonas aeruginosa & 4 \\
Proteus mirabilis & 2 \\
Enterococcus faecalis & 1 \\
\hline
\end{tabular}

Tablo 3. Treatment options

\begin{tabular}{ll}
\hline Primary treatment & $\begin{array}{l}\text { Number of } \\
\text { patient }\end{array}$ \\
\hline Sole DJ stent or percutaneous nephrostomy & 32 \\
URL+DJ & 11 \\
\hline Seconder treatment & 32 \\
\hline URL+DJ & 20 \\
Flexible-ureteroscopy & 1 \\
Percutaneous nephrolithotomy & 4 \\
Extracorporeal shock wave lithotripsy & 2 \\
Sole DJ stent removal & 4 \\
Radical cystectomy & 1
\end{tabular}

DJ: Double J, URL: Ureteroscopy and laser lithotripsy 
The clinical diagnosis of RFR is difficult because its symptoms are rare and vary from asymptomatic to acute renal colic (15). Diagnosis is confirmed by serial USG or CT following the evaluation of symptoms. However, USG has low sensitivity in distinguishing urinoma from abscess and detecting the location of urinoma. Contrast-enhanced CT is highly sensitive for visualization of the location of the urinoma, its size and the demonstration of its the relationship with the kidney and the ureter, and, therefore, it provides additional information contributing to treatment planning. Contrast-enhanced CT should be considered by the emergency department physician in patients with obstructive uropathy and flank pain since RFR patients usually come from emergency departments (16). $69.8 \%$ of our patients were transferred from the emergency department.

In a study by Doehn et al. (5) evaluating 162 patients with RFR, it was found that the cause of RFR was ureteric stones in 59.9\% of subjects while no other cause was found in $27.8 \%$ and other reasons were detected in 12.3\%. In a study including 51 patients performed by Kalafatis et al. (1) ureteral stones were detected as an etiological cause of RFR in 100\% of patients (5). In our patient group, $88.4 \%$ of the patients had ureteral or kidney stones, 2.3\% had bladder tumor and 9.3\% had no cause. In this context, the most common etiology of RFR is ureteric and kidney stones while other causes can be detected as well, even though rarely.

The primary goal in RFR treatment should be reducing pressure in the upper urinary system $(1,5,16)$. JJ stent or percutaneous nephrostomy implementation is a reliable method for the treatment of patients with RFR due to URL obstructed ureteric stones combined with endourological maneuvers. However, since these patients are at risk of serious infections, it is suggested that antibiotic treatment should be initiated following the diagnosis $(1,5)$, because in these patients, the rate of reproduction in urine culture is considerably high. This rate was found to be $34.9 \%$ in our study and as $27.4 \%$ in a study by Doehn et al. (5). For that reason, we think that patients who will undergo URL for stone treatment in addition to JJ stent implantation should be evaluated in a detailed manner for preoperative infection findings.

In the study performed by Doehn et al. (5), the basic criteria for endoscopic treatment such as URL in which the stone was removed or not were reported as the patient's status (e.g. additional comorbidities), presence of systemic infections, size and location of stone versus JJ stent placement only, and consequently showed more tendency to apply UR compared to JJ stent implantation only (5). When the results that were obtained in our clinic were evaluated, our treatment tendency in order to treat patients with septicemia findings (fever, leukocytosis, CRP elevation) was to reduce urinary pressure and implement JJ stent or percutaneous nephrostomy to enable drainage. However, if there is no evidence of septicemia in a patient, we think that URL combined with endourological maneuvers can be performed. However, in this group of patients, it has been reported that the operating team should work in strict coordination in order to avoid increasing the risk of complications due to prolonged intervention period, and the low flow irrigation fluid should be used in order to avoid an increase in extravasation (1). Although the treatment with JJ stent or percutaneous nephrostomy provides a solution in acute phase, the secondary treatment for RFR may be needed. In the studies by Doehn et al. (5) and Kalafatis et al. (1), the rate of secondary treatment was reported to be $75.9 \%$ and $56.8 \%$, respectively. In our study, the rate of secondary treatment was $74.4 \%$.

If RFR is not treated at the time of diagnosis or appropriately, it may lead to serious consequences such as perirenal abscess formation, sepsis, retroperitoneal fibrosis and loss of renal function $(7,8,9,10)$. 10\% of perirenal abscesses is a delayed complication of RFR (17). In the follow-up of the patients of our study, no major complications were detected in the early and late periods.

\section{Conclusion}

Although our study was retrospective, when the clinical findings are evaluated, it can be seen that we applied URL in the primary treatment in patients without sepsis findings while we applied only JJ stent or percutaneous nephrostomy in the primary treatment in patients with sepsis findings. However, prospective randomized studies are required in order to confirm this interpretation accurately.

\section{Ethics}

Ethics Committee Approval: Our study has been approved by the Ethics Committee of Adana City Training and Research Hospital with decision number 175/2018.

Informed Consent: A consent form was completed by all participants.

Peer-review: Externally peer-reviewed.

\section{Authorship Contributions}

Surgical and Medical Practices: H.E., E.A., E.T., Y.K.E., Concept: H.E., Design: H.E., E.T., E.A., Data Collection or Processing: H.E., E.T., M.E.D., Analysis or Interpretation: Z.G.G., Y.K.E., A.B.Ş., Literature Search: E.A., U.Ü., M.E.D., Writing: H.E., E.T.

Conflict of Interest: No conflict of interest was declared by the authors.

Financial Disclosure: The authors declared that this study received no financial support. 


\section{References}

1. Kalafatis $\mathrm{P}$, Zougkas $\mathrm{K}$, Petas A. Primary ureteroscopic treatment for obstructive ureteral stone-causing fornix rupture. Int J Urol 2004;11:10581064.

2. Anderhuber F, Reimann R. Pyelorenal reflux. I. Actual and presumed routes. Morphol Med 1982;2:109-122.

3. Ashebu SD, Elshebiny YH, Dahniya MH. Spontaneous rupture of the renal pelvis. Australas Radiol 2000;44:125-127.

4. Caro DJ, Waldbarum RS. Spontaneous rupture of renal pelvis. Urology 1976;8:410-412.

5. Doehn $C_{1}$ Fiola $L$, Peter $M_{1}$ Jocham D. Outcome analysis of fornix ruptures in 162 consecutive patients. J Endourol 2010; 24:1869-1873.

6. Balsells FS, De Torres Mateos JA, Mas AG, Lopes FG. Physiopathology of spontaneous extravasation of urine in the upper urinary tract. Apropos of 24 cases. J Urol Nephrol (Paris) 1976;82:385-395.

7. Coelho RF, Schneider-Monteiro ED, Mesquita JL, Mazzucchi E, Marmo Lucon A, Srougi M. Renal and perinephric abscesses: Analysis of 65 consecutive cases. World J Surg 2007;31:431-436.

8. Shu T, Green JM, Orihuela E. Renal and perirenal abscesses in patients with otherwise anatomically normal urinary tracts. J Urol 2004;172:148-150.
9. Breun $H$, Csapo Z, Sigel A. Fornix rupture a review of pathophysiology and clinical aspects. Urologe A 1989;28:329-333.

10. Wang WY, Schur I, Wang WL. Ruptured fornix demonstrated during abscess drainage. Urology 1998;52:321-321.

11. Bernardino ME, Clennan BL. High dose urograph: Incidence and relationship to spontaneous peripelvic extravasation. AJR Am J Roentgenol 1976;127:373-376.

12. Kramer RL.Urinoma in pregnancy. Obstet Gynecol 1983;62:26-28.

13. Cooke GM, Bartucz JP. Spontaneous extravasation of contrast medium during intravenous urography. Clin Radiol 1974;25:87-93.

14. Stapor K. Calycorenal backflow. Brit J Urol 1967;39:753-758.

15. Singh I, Joshi M, Mehrotra G. Spontaneous renal forniceal rupture due to advanced cervical carcinoma with obstructive uropathy. Arch Gynecol Obstet 2009;279:915-918.

16. You JS, Chung YE, Lee JY, Lee HJ, Chung TN, Park YS, Park I. The spontaneous rupture of the renal fornix caused by obstructive nephropathy. J Emerg Med 2012;43:488-489.

17. Chapman JP, Gonzalez J, Diokno AC. Significance of urinary extravasation during renal colic. Urology 1987;30:541-545. 